\title{
WhatsApp in Brazil: mobilising voters through door-to-door and personal messages
}

\author{
Mauricio Moura \\ Graduate School of Political Management, The George Washington University, Washington D.C., \\ United States of America
}

\section{Melissa R. Michelson}

Political Science, Menlo College, Atherton, United States, melissa.michelson@menlo.edu

Published on 30 Dec 2017 | DOI: 10.14763/2017.4.775

\begin{abstract}
Multiple randomised field experiments confirm that door-to-door canvassing and live telephone calls are effective methods of moving voters to the polls, but they require significant investments of time and resources and are difficult to bring to scale. In contrast, methods such as email, text messaging, or messages posted on social media networks are less resourceintensive and are easily expanded to large numbers of target voters. In this paper, we test the effectiveness of short candidate videos sent to eligible voters using the popular smartphone application WhatsApp. Using a set of randomised field experiments conducted during the 2014 elections in Brazil, we make two contributions to the literature. First, we find that short videos delivered via WhatsApp are a powerful method of increasing turnout among teen voters, confirming our hypothesis about how today's teens think about the networked publics in which they participate. Second, we add Brazil to the list of countries in which the traditional method of door-to-door canvassing has been proven a powerful method of mobilising voters.
\end{abstract}

Keywords: WhatsApp, Micro-targeting, Turnout, Door-to-door, Mobillisation

\section{Article information}

Received: 31 Oct 2017 Reviewed: 08 Dec 2017 Published: 30 Dec 2017

Licence: Creative Commons Attribution 3.0 Germany

Competing interests: The author has declared that no competing interests exist that have influenced the text.

URL:

http://policyreview.info/articles/analysis/whatsapp-brazil-mobilising-voters-through-door-door-and-pe rsonal-messages

Citation: Moura, M. \& Michelson, M. R. (2017). WhatsApp in Brazil: mobilising voters through door-todoor and personal messages. Internet Policy Review, 6(4). https://doi.org/10.14763/2017.4.775

This paper is part of Political micro-targeting, a special issue of Internet Policy Review guestedited by Balázs Bodó, Natali Helberger, and Claes H. de Vreese. 


\section{INTRODUCTION}

Democracies are sustained by active participation of the governed. The desire to win an election (or to be reelected) motivates, in theory, the behaviour of public officials, as election results provide guidance regarding public preferences and ongoing elections serve as renewals of the social contract, providing legitimacy to elected officials. While compulsory for many citizens in some democracies, voting is voluntary for most voters, and many eligible citizens in those countries regularly fail to participate in elections. In the United States, for example, turnout in presidential elections hovers at about $60 \%$, and turnout in midterm and local elections is much lower. Turnout is also often quite low in Latin American countries (compared to Northern Europe, where it tends to be higher) without compulsory voting, including Chile ( $42 \%$ in the 2013 presidential election), Colombia (47.9\% in the 2014 presidential election), and El Salvador (60.2\% in the 2014 presidential election). Further, active voters are often unrepresentative of the broader public, raising concerns about political representation.

Political scientists have long been interested in ways to increase voter turnout. In the last 15 years, they have increasingly turned to randomised field experiments to determine best practices for getting out the vote (Druckman et al., 2011). Pioneered in the 1920s, but unpopular for many decades, interest in get-out-the-vote (GOTV) experiments was rekindled in 2000 with an experiment that employed door-to-door canvassing, live telephone calls, and direct mail to increase participation among voters in New Haven, Connecticut, USA (Gerber \& Green, 2000).

Using field experiments, scholars have identified many of the mechanisms that move citizens to vote. Face-to-face and live telephone communication increases participation, while electronic, mass media, and mailed communications (messages delivered via robocalls, mailers, leaflets, email, text message, television, or radio), often referred to as indirect methods, tend to have weak to negligible effects (Green \& Gerber, 2015; García Bedolla \& Michelson, 2012). There are some important caveats to these general findings. For example, impersonal methods such as direct mail or robocalls that include a social pressure component have been found to effectively increase turnout (Green, Aronow, \& McGrath, 2013). However, social pressure messages can generate voter backlash, making these kinds of messages less attractive to candidates and campaigns (Matland \& Murray, 2013; Mann, 2010).

Most of this research has been conducted in the United States, but more recent scholarship has extended GOTV work to other parts of the world, including Benin, China, England, France, India, Japan and Sweden. In the largest such effort to date, Guillaume Liégey, Arthur Muller, and Vincent Pons (2013) worked with the 2012 François Holland campaign in France, finding that door-to-door canvassing effectively moved French voters to the polls. Bhatti et al. (2016) conducted a meta-analysis of door-to-door efforts in Europe between 2005 and 2014, including experiments conducted in England, France, Italy, Spain and Sweden along with their own efforts in Denmark. They calculated an average effect of just 0.78 percentage-points, far smaller than that found for efforts conducted in the US. Further testing in contexts other than the United States is needed to better understand which best practices are universal and which are dependent on local political cultures.

A related trend in GOTV research is that target populations are increasingly difficult to reach using traditional methods, leading practitioners and scholars to explore different communication methods (Green \& Gerber, 2015; Issenberg, 2012). Door-to-door efforts, at times very powerful, are time consuming and expensive, in part because targeted voters are not 
always at home waiting to be contacted. Telephone canvassing is more cost-efficient, but targets are increasingly unwilling to answer calls from unknown or unidentified numbers, making strong contact rates, and thus treatment effects, elusive. Door-to-door and telephone canvassing effectiveness is also sensitive to call quality, adding challenges of supervision to GOTV campaigns (Nickerson, 2007a; Mann and Klofstad, 2015). In contrast, the content and quality of GOTV messages delivered via text messages, email, or social networking sites are more easily controlled, and researchers are increasingly exploring how to make these methods effective. Green and Gerber identify three advantages to the use of digital campaigns. First, cost. Not including the cost of content production, email, text, and video messages can, sometimes, be distributed at negligible expense. Second, recipients can forward these messages to their family and friends, providing additional (free) exposure and even the possibility of a message going viral. Finally, the flexibility of the platform allows for improved behaviour- and demographicbased targeting, two-way communication, and embedded links to websites where recipients can learn more about a candidate or get involved in a campaign. The pressing question is whether such campaigns are effective; experiments conducted to date, which we review below, provide limited evidence that these campaigns are able to move voters to the polls.

In this paper, we provide evidence that such a strategy can have dramatic results. In a set of GOTV experiments conducted in 2014 in Brazil, using the WhatsApp smartphone app and a series of messages developed by real candidates, we find large increases in voter turnout among younger voters randomly assigned to receive WhatsApp video messages. To our knowledge, these experiments are the first to test the power of WhatsApp video messages as a voter mobilisation tool.

These experiments are also the first to intentionally test GOTV messages in a regular election in Brazil. A 2008 field experiment during a mayoral runoff election in São Paulo that aimed to test the effects of information on vote choice also found that informing voters that a challenger had a record of corruption decreased turnout by 1.9 percentage points (de Figueiredo, Hidalgo, \& Kasahara, 2014). Fujiwara (2015), exploiting the discontinuous introduction of electronic voting in various states in Brazil in the mid-199os, finds that the introduction of the technology generates significant increases in voter participation among less educated citizens. Another earlier GOTV effort in Brazil focused on an online June 2014 participatory budgeting vote in Rio Grande do Sul in southern Brazil. Individuals assigned to the treatment condition were each sent three emails and a mobile phone text message, and were 4.7 percentage-points more likely to vote compared to those assigned to the control condition (Peixoto, Sjoberg, \& Mellon, 2017).

The remainder of this paper proceeds as follows. First, we review the GOTV literature, focusing on distinctions drawn in previous scholarship between personal and impersonal methods of contact with targeted voters. We then briefly describe the breadth of the use of smartphones and messaging applications such as WhatsApp in Brazil and elsewhere, setting the stage for our hypotheses. Following a description of these hypotheses, we turn to the context of the Brazilian elections and the candidates with whom we partnered to conduct these experiments. We then describe and discuss our results.

\section{SECTION 1: PERSONAL VS. IMPERSONAL GOTV TACTICS}

The bulk of GOTV experimental field literature finds that the strongest effects on turnout are 
produced through personal interactions with voters. Gerber and Green (2000) argue, based on the US case, that low turnout during the second half of the $20^{\text {th }}$ century is possibly due to the rise of impersonal campaign methods, such as direct mail and television advertisements, and the decline of personal contact in mass organisations (Rosenstone \& Hansen, 1993; Putnam, 2000). While more expensive, hundreds of field experiments in a variety of electoral contexts and with different target populations have found that face-to-face contact with voters is the most powerful mobilisation method (Green \& Gerber, 2015; García Bedolla \& Michelson, 2012). Personal telephone calls are also a very effective, albeit expensive, method, particularly when callers are trained to be conversational and are well supervised (Nickerson, 2007b; Mann \& Klofstad, 2015). When callers who have made a commitment to vote are re-contacted just before the election, telephone calls can generate increases in turnout equal to or surpassing those generated by single door-to-door contacts (Michelson, García Bedolla, \& McConnell, 2009).

In contrast, most methods of impersonal GOTV have proven weak to ineffective in moving voters to the polls. Impersonal methods include messages sent directly to individual voters, such as direct mail (Green \& Gerber, 2015), text messages (Dale \& Strauss, 2009; Malhotra et al., 2011), email messages (Nickerson, 2006; Malhotra et al., 2012), and robocalls (Green \& Gerber, 2015), and also mass media messages such as television and radio advertisements (Green \& Vavreck, 2006; Panagopoulos \& Green, 2011) and banner messages and general paid advertisements on Facebook (Bond et al., 2012; Collins, Kalla, \& Keane, 2014). Moving beyond the US, scholars in Denmark found a small but statistically significant effect of text messages (Bhatti et al., 2017). A text message experiment in Norway (Bergh, Christensen, \& Matland, 2016) generated similar results among Norwegian natives, and even stronger effects among immigrants. As noted above, an experiment in Brazil in 2014 using a combination of emails and text messages had a relatively large effect on turnout (Peixoto, Sjoberg, \& Mellon, 2017).

Direct mail that includes a social pressure component, such as information about the voting recipient and her neighbours, generates larger increases in turnout (Gerber, Green, \& Larimer, 2008; Panagopoulos, 2010; Rogers et al., 2017); however, as noted above, these tactics also generate significant negative backlash from recipients and the media (Matland \& Murray, 2013; Mann, 2010). Pooling together 85 GOTV distinct studies conducted between 1998 and 2014, Green and Gerber (2015) find that sending a piece of mail increases turnout by about $3 / 4$ of a percentage point, although social pressure mailers have an average effect of 2.3 percentage points. Mail has also been found to be effective in experiments conducted in the UK and Ireland (Fieldhouse et al., 2013; Regan, 2013).

Other small, labour-intensive efforts have also generated sizeable increases in turnout using impersonal messages sent within personal networks, including the use of Facebook status updates (Teresi \& Michelson, 2014; Haenschen, 2016) and friend-to-friend email messages (Davenport, 2008).

The bulk of the experimental field literature on voter mobilisation has emphasised the importance of social connectedness (Green \& Gerber, 2015), which is challenged by Noticeable Reminder Theory (Dale \& Strauss, 2009). Dale and Strauss posit that the strong effect of text messages proves that it is not the personal nature of other GOTV messaging methods that is key to their effectiveness, but rather that they are noticeable. This is consistent with the disparate findings of email and Facebook experiments noted above: emails sent by personal friends or trusted sources (Davenport, 2008; Malhotra et al., 2012) and Facebook status messages from friends (Teresi and Michelson, 2014; Haenschen, 2016) generate relatively large increases in turnout, while email sent from other sources (Nickerson, 2007b; Stollwerk, 2015) and Facebook 
banner advertisements (Bond et al., 2012; Collins, Kalla, and Keane, 2014) generate small or negligible increases in turnout.

In sum, previous experimental research finds that GOTV messages sent via impersonal delivery methods will be effective if they are interpreted as personal by recipients, or if they are more noticeable. Here, we explore a third possibility: that while door-to-door canvassing will be interpreted as personal by all recipients, messages delivered by text message will be interpreted as personal by younger recipients and as impersonal by older recipients. We further hypothesise that text message reminders to vote will be more effective among younger recipients because they are more likely than older voters to have mobile internet.

The use of online media is widespread among today's youth. According to a survey of American 13- to 17 -year-olds conducted in early 2012, teens are avid, daily users of social media: $75 \%$ have a profile on a social networking site and 68\% text every day (Common Sense Media, 2012). Thompson (2014) reports that many younger smartphone users are more likely to use messaging applications (apps) than email, and they use these apps multiple times a day. Today's youth use their mobile phones and the internet to establish community and connections (Agger, 2013). Teenagers are coming of age in an era of mediated communication, where lines between physical and digital interaction are increasingly entangled and blurry (boyd, 2014). According to boyd, participation in social media is an essential part of the lives of today's teenagers. "[E]ngagement with social media is simply an everyday part of life, akin to watching television and using the phone" (boyd, 2014: 22). "When teens turn to networked publics, they do so to hang out with friends and be recognized by peers. They share in order to see and be seen" (boyd, 2014: 217).

In sum, for some American younger voters, particularly teenagers, interactions with their online publics may be just as personal and meaningful as face-to-face interactions. This suggests GOTV messages delivered via those communities may be just as powerful for teenagers as door-to-door canvassing and phone calls are for older voters. As described below, we test and find significant support for this hypothesis from our GOTV experiments in Brazil.

\section{SECTION 2: SMARTPHONES (IN BRAZIL)}

First introduced to consumers in the late 1990s, smartphones are mobile telephones that include an operating system, allowing access to the internet and the use of third party apps. Feature phones (traditional mobile phones) can send and receive text messages; smartphones allow users to send not just texts but also photos and videos using apps such as Facebook Messenger, Skype, Snapchat, and WhatsApp. Facebook Messenger dominates the market in the United States; globally, smartphone users prefer WhatsApp (Statista, 2017a; Statista, 2017b).

Smartphone use is widespread in Brazil, fueled by the recent development of $4 \mathrm{G}$ networks and tax-break prompted investment in the local market (partly in preparation for the 2014 FIFA World Cup and the 2016 Summer Olympics). As of January 2015, Brazil boasted the largest smartphone market in Latin America; nearly one in three Brazilians have internet access on their mobile phone, and WhatsApp has over 45 million users (over 20\% of Brazilians). Businesses, political candidates, and even the country's national soccer team have turned to WhatsApp as a means of communicating with the public. In early 2014, a Head \& Shoulders shampoo campaign used short, sharable WhatsApp videos featuring Joel Santana, head coach for the Brazilian national team Vasco da Gama; in May 2014, Hellmann's mayonnaise used 
WhatsApp to promote the product; June 2014 saw a WhatsApp campaign for Chivas Regal whiskey (Teixeira, 2014).

WhatsApp is also increasingly popular with politicians. In the 2014 presidential elections, candidates used WhatsApp to communicate with voters, while voters used it to share political preferences. One presidential candidate, Aécio Neves, was a robust user of the app; his party sent 33 WhatsApp messages during the campaign, one of which became the most popular piece of content circulated during the elections (Glickhouse, 2015). Young candidates in legislative races also used WhatsApp to interact with voters (Idoeta, 2014). On the last day of the 2014 elections, former President Dilma sent WhatsApp messages to 35 million voters.1

\section{SECTION 3: CONTEXT}

We began our GOTV experiments by inviting various candidates for the federal and state legislatures in Brazil to cooperate with us. Of 28 invited candidates, four agreed to participate. These included candidates for the Federal Congress in Rio de Janeiro and Amazonas and candidates for the State Congress in Santa Catarina (Florianópolis) and São Paulo. The candidates included at least one member of all three major political parties in Brazil: the Workers' Party (PT) in São Paulo, the Brazilian Social Democracy Party (PSDB) in Amazonas, and the Brazilian Democratic Movement Party (PMDB) in Rio de Janeiro and Santa Catarina. Two candidates were challengers and two were incumbents; three were successfully elected (the two incumbents and one challenger). In order to maintain their anonymity, and in conformity with Brazil's research code (the Fundo de Amparo a Pesquisa do Estado de Sao Paulo, FAPESP), we refer throughout the remainder of this paper only to the names of the four municipalities in which the candidates were located.

In each geographic area, the candidate reached out to voters in the treatment group with information about themselves, their record, and their platform. Candidates controlled the content of the messages; our role was to randomise the treatment and control groups and instruct the campaigns about which voters to target with each type of message (a door-to-door visit, a robocall, an email, or a WhatsApp video message), similar to how Alan Gerber and his colleagues partnered with Rick Perry in Texas in 2006 (Gerber et al., 2011).

While voting is compulsory in Brazil, the law exempts those aged 16 and 17 and over age 70 (as well as illiterate voters). In 2014, these two segments represented $8.67 \%$ of eligible voters (Table 1). Our experiments targeted very small percentages of voters in each geographic area: 1,181 people in Rio de Janeiro, 833 in São Paulo, 487 in Santa Catarina, and 366 in Amazonas.

Table 1: Eligible voters in Brazil for whom voting is not compulsory, by age

\begin{tabular}{|l|l|l|l|l|l|}
\hline & \multicolumn{2}{|l|}{$16-17$ years old } & \multicolumn{2}{l|}{$70+$ years old } & All eligible voters \\
\hline & N & $\%$ & N & $\%$ & N \\
\hline Amazonas & 38,278 & 1.72 & 119,421 & 5.36 & $2,226,891$ \\
\hline Rio de Janeiro & 75,487 & 0.62 & $1,186,728$ & 9.77 & $12,141,145$ \\
\hline Santa Catarina & 45,715 & 0.94 & 345,121 & 7.10 & $4,859,324$ \\
\hline São Paulo & 231,076 & 0.72 & $2,519,149$ & 7.87 & $31,998,432$ \\
\hline
\end{tabular}




\begin{tabular}{|l|l|l|l|l|l|}
\hline Brazil & $1,719,404$ & 1.20 & $10,670,989$ & 7.47 & $142,825,280$ \\
\hline
\end{tabular}

Source: TSE 2014. Illiterate voters are also exempt from compulsory voting laws in Brazil. They are not included in these experiments.

Another important aspect of the context of these experiments is that the 2014 elections in Brazil were extremely competitive, with the second round re-election of Dilma Rousseff of the PT as president of Brazil by just 3 percentage points over her opponent, Aécio Neves of the PSDB, $51.64 \%$ to $48.36 \%$, with over 105.5 million valid votes cast.2 Some observers credited the result to a split between wealthier voters supporting the PSDB and the poor voting for the PT. Others claimed the PT victory was due to northeastern voters supporting Rousseff (the region is the main beneficiary of federal government income transfer programmes), while Neves performed best in more developed regions such as São Paulo and among those with higher levels of income and education. Other observers focused on urban areas, noting that in these municipalities support tends to go to the party in power, reflecting the dependence of those regions on the state.

Varying levels of support for the PT and PDSB are relevant to the GOTV efforts examined here because we partnered with candidates to deliver the treatment messages. In other words, responses to these calls to vote may partially reflect support for or opposition to the particular candidates and parties making the GOTV requests. In São Paulo, for example, the candidate we partnered with was affiliated with the PT; the PT lost in São Paulo in the presidential, state governor, and state senate elections, and lost seats in the federal and state congresses. The PT candidate's efforts to increase turnout among the target groups in that area may therefore have been less successful than otherwise because they were advocating turnout in favour of a candidate from a locally unpopular political party. In Amazonas, our partnering candidate was a PSDB federal congress candidate. Outreach was focused on eligible voters in the city of Manaus, whose mayor is a famous member of the party. Our partnering candidates in Rio de Janeiro and Santa Catarina were from the PMDB, one each for the federal and state legislatures. The PMDB has strong support in Rio de Janeiro, including the elected mayor and governor, but the party there is divided and many members supported PSDB's Aécio Neves for the presidency.

Another aspect of the Brazilian context relevant to our experiments is the different socioeconomic status of targeted voters. For those targeted via WhatsApp in particular, levels of income and employment serve as proxies for smartphone ownership and thus the ability to receive and respond to the GOTV messages. These socioeconomic indicators may also serve as proxies for support for the two political parties, and thus openness to persuasion when receiving a blandishment to vote from a candidate. As shown in Table 2, Amazonas has the lowest levels of per capita income and education and the highest rate of unemployment; thus, it is possible that GOTV outreach in Amazonas that is dependent on personal ownership of a smartphone will be less successful compared to similar outreach in other areas. In other words, we expect the failure-to-treat effect to be larger.

Table 2: Social indicators

\begin{tabular}{|l|l|l|l|l|l|}
\hline & Amazonas & $\begin{array}{l}\text { Rio de } \\
\text { Janeiro }\end{array}$ & $\begin{array}{l}\text { Santa } \\
\text { Catarina }\end{array}$ & $\begin{array}{l}\text { São } \\
\text { Paulo }\end{array}$ & Brazil \\
\hline Per capita average income & $\mathrm{R} \$ 461$ & $\mathrm{R} \$ 1,193$ & $\mathrm{R} \$ 1,245$ & $\mathrm{R} \$ 1,432$ & $\mathrm{RS} 1,052$ \\
\hline Unemployment rate & $9.7 \%$ & $7.5 \%$ & $3.1 \%$ & $6.6 \%$ & $6.5 \%$ \\
\hline
\end{tabular}




\begin{tabular}{|l|l|l|l|l|l|}
\hline Gini coefficient & 0.478 & 0.489 & 0.436 & 0.474 & 0.498 \\
\hline National GDP participation & $1.5 \%$ & $11.5 \%$ & $4 \%$ & $32.1 \%$ & $100 \%$ \\
\hline $\begin{array}{l}\text { Unschooled and incomplete } \\
\text { basic education }\end{array}$ & 53.6 & 41.5 & 45.5 & 41.9 & 50.2 \\
\hline $\begin{array}{l}\text { Complete basic education } \\
\text { and incomplete high school }\end{array}$ & 16.2 & 18.9 & 19.5 & 18.7 & 17.4 \\
\hline $\begin{array}{l}\text { Complete high school and } \\
\text { incomplete higher } \\
\text { education }\end{array}$ & 24.1 & 28.1 & 24.8 & 26.8 & 23.5 \\
\hline Complete higher education & 5.3 & 10.9 & 9.7 & 11.7 & 8.3 \\
\hline
\end{tabular}

Source: IBGE/Censo, 2010; IBGE, 2012; IBGE, 2015; PNAD, 2013. The Gini coefficient is a World Bank estimate of inequality; lower values indicate less inequality (see http://data.worldbank.org/indicator/SI.POV.GINI)

\section{SECTION 4: HYPOTHESES}

Our GOTV experiments in Brazil tested the effectiveness of door-to-door canvassing, email messages, robocalls, and WhatsApp video messages. As noted above, voting is compulsory in Brazil for adults aged 18 to 70 ; thus, we focused on those segments of the electorate not included in compulsory voting laws (those aged 16 to 17 or over 70). Given previous GOTV experimental results, we hypothesised that door-to-door canvassing would be the most effective method of increasing turnout, that WhatsApp would have a statistically significant effect in turnout among younger voters, and that email messages and robocalls would fail to mobilise voters. Details of the various methods used in the experiments are provided below. We also expected older voters to be easier to move across the cusp of deciding to vote due to an established voting habit from years of compulsory voting, and that older voters would be more easily contacted via door-todoor visits than teen voters.

\section{EXPERIMENTAL DESIGN AND RESULTS}

Methods used in each municipality varied based on the preferences of the local candidate (see Table 3). Within each zone (determined by the candidates), treatment conditions were assigned randomly by residential section. One section was randomly assigned to each of the treatment groups and to the control group. Rio de Janeiro and São Paolo each have 20 sections, Santa Catarina has 16 sections, and Amazonas has 15 sections. Unfortunately, we cannot test for covariate balance using data from past elections because voter history information is unavailable. Instead, we test for balance in the covariates for which data is available: age and gender (see Appendix). Because treatment conditions were assigned randomly by residential section, the instrumental variable analyses below cluster by section to provide robust standard error estimates. There is only one section per zone assigned to each type of GOTV outreach.

Table 3. 2014 Brazilian GOTV experiments by municipality

\begin{tabular}{|l|l|l|l|l|}
\hline & Amazonas & Rio de Janeiro & Santa Catarina & São Paulo \\
\hline Door-to-door & & $\mathrm{X}$ & & $\mathrm{X}$ \\
\hline
\end{tabular}




\begin{tabular}{|l|l|l|l|l|}
\hline Email & & $\mathrm{X}$ & $\mathrm{X}$ & $\mathrm{X}$ \\
\hline Robocalls & $\mathrm{X}$ & & $\mathrm{X}$ & $\mathrm{X}$ \\
\hline WhatsApp & $\mathrm{X}$ & $\mathrm{X}$ & $\mathrm{X}$ & \\
\hline
\end{tabular}

After the election, as described in Table 3, we compared turnout in the treatment and control groups for each GOTV method and for each age group (older than 70 and younger than 18). Turnout data was collected at the individual level and is based on validated turnout information from the government. Contact for the door-to-door canvassing arms of the experiments is measured as the canvasser successfully speaking face-to-face with the targeted voter. Because not all individuals in the groups targeted for door-to-door canvassing were successfully contacted, we conduct 2 SLS regression to take into consideration the failure to contact some voters by regressing contact on assignment to the treatment group. For the WhatsApp, email, and robocall treatment groups, we assume all targeted individuals were successfully treated. Note that the subject line in the email messages included language about participating in the election, which means that even those individuals who did not open the messages were likely exposed to some information about voting.

\section{WhatsApp messages}

Looking first at the WhatsApp treatment, we see significant effects in several experiments (Table 4). Youth in Rio de Janeiro and Santa Catarina who were sent a WhatsApp message about the election were significantly more likely to vote, by 76.51 percentage points in Rio and by 44.05 percentage points in Santa Catarina; both of these differences are statistically significant at the $p$ $<.01$ level. In Amazonas, the difference in youth turnout is much smaller, at 3.67 percentagepoints, and is not statistically significant. Efforts to increase turnout among older voters using WhatsApp messages were also consistently ineffective for all three locations. Below, we speculate about reasons for the size of these effects.

Table 4. WhatsApp effects

\begin{tabular}{|l|l|l|l|}
\hline & $\begin{array}{l}\text { \% voting, control } \\
\text { group }\end{array}$ & $\begin{array}{l}\text { \% voting, treatment } \\
\text { group }\end{array}$ & Intent-to-treat effect \\
\hline Amazonas $>70$ & $\begin{array}{l}14 \cdot 47 \\
(11 / 76)\end{array}$ & $\begin{array}{l}11.76 \\
(8 / 68)\end{array}$ & $\begin{array}{l}-2.71 \\
(5.68)\end{array}$ \\
\hline Amazonas $<18$ & $\begin{array}{l}16.33 \\
98 / 49)\end{array}$ & $\begin{array}{l}20.00 \\
(9 / 45)\end{array}$ & $\begin{array}{l}3.67 \\
(8.02)\end{array}$ \\
\hline Rio de Janeiro $>70$ & $\begin{array}{l}10.65 \\
(18 / 169)\end{array}$ & $\begin{array}{l}14.92 \\
(27 / 181)\end{array}$ & $\begin{array}{l}4.27 \\
(3.58)\end{array}$ \\
\hline Rio de Janeiro $<18$ & $\begin{array}{l}12.38 \\
(13 / 105)\end{array}$ & $\begin{array}{l}88.89 \\
(96 / 108)\end{array}$ & $\begin{array}{l}76.51^{* *} \\
(4.43)\end{array}$ \\
\hline Santa Catarina $>70$ & $\begin{array}{l}11.11 \\
(9 / 81)\end{array}$ & $\begin{array}{l}12.5 \\
(9 / 72)\end{array}$ & $\begin{array}{l}1.39 \\
(5.25)\end{array}$ \\
\hline Santa Catarina $<18$ & $\begin{array}{l}14.29 \\
(6 / 42)\end{array}$ & $\begin{array}{l}58.33 \\
(28 / 48)\end{array}$ & $\begin{array}{l}44.05^{* *} \\
(9.23)\end{array}$ \\
\hline
\end{tabular}

$* *=p<.01$, two-tailed

As noted above (Table 2) Rio de Janeiro and Santa Catarina are states with higher than average 
per capita incomes, education and employment, compared to Amazonas. Thus, individuals in Amazonas are less likely to have smartphones on which they can access WhatsApp. For this experiment, candidates sent messages to mobile phone numbers. We neither have information about the type of mobile phone the individuals used nor are we able to determine if intended recipients successfully received the WhatsApp messages.

\section{Door-to-door canvassing}

We next examine door-to-door treatment effects, controlling for contact (Table 5). Door-to-door canvassing was conducted in São Paulo and Rio de Janeiro. For all four groups, individuals randomly assigned to the treatment group were more likely to vote than were those randomly assigned to the control group.

Table 5. Door-to-door canvassing effects

\begin{tabular}{|l|l|l|l|l|l|}
\hline & $\begin{array}{l}\text { \% voting, } \\
\text { control } \\
\text { group }\end{array}$ & $\begin{array}{l}\text { \% voting, } \\
\text { treatment } \\
\text { group }\end{array}$ & $\begin{array}{l}\text { Intent-to-treat } \\
\text { effect } \\
\text { (SE) }\end{array}$ & $\begin{array}{l}\text { Contact } \\
\text { rate }\end{array}$ & $\begin{array}{l}\text { Treatment-on-treated } \\
\text { effect } \\
\text { (SE) }\end{array}$ \\
\hline $\begin{array}{l}\text { Rio de } \\
\text { Janeiro } \\
>70\end{array}$ & $\begin{array}{l}10.65 \\
(18 / 169)\end{array}$ & $\begin{array}{l}77.04 \\
(151 / 196)\end{array}$ & $\begin{array}{l}66.39^{* *} \\
(3.93)\end{array}$ & $\begin{array}{l}95.92 \\
(188 / 196)\end{array}$ & $\begin{array}{l}69.22^{* *} \\
(0.00)\end{array}$ \\
\hline $\begin{array}{l}\text { Rio de } \\
\text { Janeiro } \\
<18\end{array}$ & $\begin{array}{l}12.38 \\
(13 / 105)\end{array}$ & $\begin{array}{l}75.00 \\
(93 / 124)\end{array}$ & $\begin{array}{l}62.62^{* *} \\
(5.18)\end{array}$ & $\begin{array}{l}97.58 \\
(121 / 124)\end{array}$ & $\begin{array}{l}64.17^{* *} \\
(0.00)\end{array}$ \\
\hline $\begin{array}{l}\text { São } \\
\text { Paulo } \\
>70\end{array}$ & $\begin{array}{l}20.31 \\
(26 / 128)\end{array}$ & $\begin{array}{l}60.98 \\
(75 / 123)\end{array}$ & $\begin{array}{l}40.66^{* *} \\
(5.66)\end{array}$ & $\begin{array}{l}82.93 \\
(102 / 123)\end{array}$ & $\begin{array}{l}49.03^{* *} \\
(0.00)\end{array}$ \\
\hline $\begin{array}{l}\text { São } \\
\text { Paulo } \\
<18\end{array}$ & $\begin{array}{l}11.46 \\
(11 / 96)\end{array}$ & $\begin{array}{l}30.36 \\
(17 / 56)\end{array}$ & $\begin{array}{l}18.90^{* *} \\
(6.38)\end{array}$ & $\begin{array}{l}87.50 \\
(49 / 56)\end{array}$ & $\begin{array}{l}21.60^{* *} \\
(0.00)\end{array}$ \\
\hline
\end{tabular}

** $=p<.001$, TOT robust clustered standard errors by residential section.

The effect of the door-to door visits persists in a 2SLS analysis, using assignment to the treatment group as an instrument for contact and clustering by section to provide robust standard errors. In Rio de Janeiro, instrumental variable regression generates a treatment-ontreated estimate of 69.22 percentage points $(\mathrm{SE}=0.00)$ for older voters and 64.17 percentage points $(\mathrm{SE}=0.00)$ for younger voters. The effects are weaker but still impressive in São Paulo, where the estimated treatment-on-treated effects are 49.03 percentage points $(\mathrm{SE}=0.00)$ for older voters and 21.60 percentage points $(\mathrm{SE}=0.00)$ for younger voters. These effects are much larger than those found in previous door-to-door GOTV field experiments, although they are on par with some results from California (García Bedolla \& Michelson, 2012). We speculate below about reasons for the unusual magnitude of our findings.

\section{Email messages and robocalls}

We next examined the effect of email messages (Table 6) and robocalls (Table 7). As expected based on previous research, these methods have no measurable effects on turnout; differences in voter turnout between the control and treatment groups are small, with large standard errors.

Table 6. Email effects

\begin{tabular}{|l|l|l|l|}
\hline & $\begin{array}{l}\text { \% voting, control } \\
\text { group }\end{array}$ & $\begin{array}{l}\text { \% voting, treatment } \\
\text { group }\end{array}$ & $\begin{array}{l}\text { Intent-to-treat effect } \\
\text { (SE) }\end{array}$ \\
\hline
\end{tabular}




\begin{tabular}{|l|l|l|l|}
\hline Rio de Janeiro $>70$ & $\begin{array}{l}10.65 \\
(18 / 169)\end{array}$ & $\begin{array}{l}9.64 \\
(16 / 166)\end{array}$ & $\begin{array}{l}-1.01 \\
(3.31)\end{array}$ \\
\hline Rio de Janeiro <18 & $\begin{array}{l}12.38 \\
(13 / 105)\end{array}$ & $\begin{array}{l}13.64 \\
(18 / 132)\end{array}$ & $\begin{array}{l}1.26 \\
(4.42)\end{array}$ \\
\hline Santa Catarina $>70$ & $\begin{array}{l}11.11 \\
(9 / 81)\end{array}$ & $\begin{array}{l}10.29 \\
(7 / 68)\end{array}$ & $\begin{array}{l}-0.82 \\
(5.13)\end{array}$ \\
\hline Santa Catarina $<18$ & $\begin{array}{l}14.29 \\
(6 / 42)\end{array}$ & $\begin{array}{l}17.02 \\
(8 / 47)\end{array}$ & $\begin{array}{l}2.73 \\
(7.81)\end{array}$ \\
\hline São Paulo >70 & $\begin{array}{l}20.31 \\
(26 / 128)\end{array}$ & $\begin{array}{l}21.57 \\
(22 / 102)\end{array}$ & $\begin{array}{l}1.26 \\
(5.42)\end{array}$ \\
\hline São Paulo <18 & $\begin{array}{l}11.46 \\
(11 / 96)\end{array}$ & $\begin{array}{l}9.33 \\
(14 / 150)\end{array}$ & $\begin{array}{l}-2.13 \\
(3.96)\end{array}$ \\
\hline
\end{tabular}

Table 7. Robocall effects

\begin{tabular}{|l|l|l|l|}
\hline & $\begin{array}{l}\text { \% voting, control } \\
\text { group }\end{array}$ & $\begin{array}{l}\text { \% voting, treatment } \\
\text { group }\end{array}$ & Intent-to-treat effect \\
\hline Amazonas $>70$ & $\begin{array}{l}14.47 \\
(11 / 76)\end{array}$ & $\begin{array}{l}10.98 \\
(9 / 82)\end{array}$ & $\begin{array}{l}-3.50 \\
(5 \cdot 32)\end{array}$ \\
\hline Amazonas $<18$ & $\begin{array}{l}16.33 \\
98 / 49)\end{array}$ & $\begin{array}{l}13.04 \\
(6 / 46)\end{array}$ & $\begin{array}{l}-3.28 \\
(7.34)\end{array}$ \\
\hline Santa Catarina $>70$ & $\begin{array}{l}11.11 \\
(9 / 81)\end{array}$ & $\begin{array}{l}7.89 \\
(6 / 76)\end{array}$ & $\begin{array}{l}-3.22 \\
(4.72)\end{array}$ \\
\hline Santa Catarina $<18$ & $\begin{array}{l}14.29 \\
(6 / 42)\end{array}$ & $\begin{array}{l}9.43 \\
(5 / 53)\end{array}$ & $\begin{array}{l}-4.85 \\
(6.66)\end{array}$ \\
\hline São Paulo $>70$ & $\begin{array}{l}20.31 \\
(26 / 128)\end{array}$ & $\begin{array}{l}15.69 \\
(16 / 102)\end{array}$ & $\begin{array}{l}-4.63 \\
(5.14)\end{array}$ \\
\hline São Paulo $<18$ & $\begin{array}{l}11.46 \\
(11 / 96)\end{array}$ & $\begin{array}{l}9.21 \\
(7 / 76)\end{array}$ & $\begin{array}{l}-2.25 \\
(4.72)\end{array}$ \\
\hline
\end{tabular}

\section{CONCLUSION: IMPLICATIONS}

Hundreds of field experiments conducted over the past two decades have led to significant advances in our understanding of how to increase voter turnout. Modeling the path-breaking work of Gerber and Green (2000), most of these experiments have used door-to-door canvassing or live telephone banks to contact voters. We now know the importance of particular variations in script and the use of trusted and well-trained canvassers, among other insights, but also have a better understanding of the cost of these campaigns. Simply stated, getting out the vote via personal door-to-door visits or phone calls in the US is extremely expensive, estimated at US\$20 per vote or more (costs in Brazil are similar). The logistics of these campaigns bring additional challenges, such as how to contact voters who do not necessarily want to be contacted and are screening their phone calls. Thus, in the name of cost-efficiency and high contact rates, newer GOTV experiments have branched out into the use of internet- and mobile phone-based methods of contact including email, Facebook, and text messages. Here, we extend that research to Brazil, testing traditional methods of door-to-door canvassing, email, and robocalls, as well as 
WhatsApp video messages.

Our most interesting findings come from the WhatsApp experiments. In two of three experiments targeting young voters, these video messages were very effective at increasing turnout. The lower socioeconomic context of Amazonas likely means fewer targeted mobile phone numbers in that area were owned by smartphone users, possibly generating very low compliance levels. Experiments targeting older voters, whom we assume are less likely to be WhatsApp users, do not increase voter turnout.

The use of multimedia text messaging is widespread and growing in both the US and around the world. While not all registered or eligible voters are WhatsApp users, the expanding use of smartphone-based communication and lack of legislation that constrains WhatsApp use provides an opportunity to reach large numbers of voters at minimal expense. GOTV using these messages has the potential to have large effects on turnout among the increasingly wired populations of industrialised and developing countries. Additional experiments are needed to test if similar effects can be generated in different contexts and with different messages, and to determine the number of messages needed to maximise turnout.

Hundreds of GOTV experiments have been conducted over the last two decades. The overarching conclusion from this work, with few exceptions, is that moving large numbers of voters to the polls requires reminders to vote that use social pressure, are delivered via a personal socio-cultural interaction, or that constitute a noticeable reminder. We find that WhatsApp messaging is a powerful method of moving youth to vote in Brazil. This is a potentially powerful and cost-effective method of increasing turnout in a traditionally lowturnout group (young voters). As social networks and interpersonal interactions move online and onto smartphone-based apps, both for youth and older cohorts, GOTV methods should follow.

Consistent with prior research, we also find door-to-door canvassing to be an effective and powerful method of increasing voter turnout. Statistically significant and substantively large increases in turnout were generated in four experiments with older and younger voters in Rio de Janeiro and São Paulo. The results are weakest among younger voters in São Paulo; this may reflect the context of the election for that population. Recall that the candidate in São Paulo was affiliated with the PT, which, while successful in the presidential runoff election, was unpopular with local voters. This lack of popularity may have mitigated the effectiveness of the local candidate's GOTV messages. This variation aside, the effect of the door-to-door campaigns was substantial, exceeding the usual expected effect sizes based on experiments in other countries and in other contexts. This may reflect the uniqueness of a robust, individualised door-to-door campaign in Brazil. While campaigns in the US often include individual-level outreach to voters, including door-to-door visits, campaigns in Brazil tend to instead rely almost exclusively on television and radio advertisements to reach the voting public. This reflects the structure of the voting system, including proportional representation (rather than a district system, which would encourage individual candidates to reach out to local voters using direct methods of communication) as well as compulsory voting laws that affect most citizens.

Results from the email and robocall campaigns are also consistent with prior research, (with the notable exception of the email and text message campaign conducted in Brazil by Peixoto, Sjoberg, \& Mellon, 2017). Examining intent-to-treat effects, we find little evidence that email or robocalls move voters to the polls. Further experiments with larger target populations may be necessary to better understand if and when email messages from candidates effectively increase participation among Brazilian voters, or whether multiple "touches" are needed to make such 
tactics effective.

The observed effects in two of three WhatsApp experiments, and in the door-to-door experiments, are unusually large. It may be that further GOTV experiments in similar contexts will regress to a smaller mean, and that these results are outliers. Occasional door-to-door canvassing experiments have found effects of the magnitude observed here, including a campaign in Riverside County, California in 2006 that generated a treatment-on-treated effect of 43.1 percentage points (García Bedolla \& Michelson, 2012), but most door-to-door efforts generate more modest results. On the other hand, the large size of these effects may reflect the specific context and nature of our experiments. It may be that voters in Brazil are particularly susceptible to messages about voting due to the presence of compulsory voting for most citizens in the country. In other words, voters in countries with compulsory voting who are exempt from those laws may have internalised local norms about voting, or they may be concerned that the messages inviting them to participate are an indication that they are required to do so. Further experiments in countries with partial or widespread compulsory voting laws will help better establish the effect of this context on the effect of GOTV messages aimed at voters in those countries who are not required to vote; post-experimental surveys of individuals moved to the polls in such instances may also be helpful. On the other hand, such effects may wear off if this particular targeting mechanism becomes more regularly applied, not only for political microtargeting but also for general advertising. In other words, voters and consumers may develop immunity to widely-used communication methods. Again, future research is needed to determine whether these strong tactics become less noticeable as their frequency of use increases. 


\section{REFERENCES}

Agger, B. (2013). Texting towards utopia: Kids, writing, and resistance. New York, NY: Paradigm Publishers.

Bergh, J., Christensen, D. A., \& Matland, R. E. (2016). Getting out the vote. Experiments in voter mobilization among immigrants and natives in Norway. Rapport-Institutt for samfunnsforskning. Retrieved from https://brage.bibsys.no/xmlui/handle/11250/2442442

Bhatti, Y., Dahlgaard, J. O., Hansen, J. H., \& Hansen, K. M. (2016). Is Door-to-Door Canvassing Effective in Europe? Evidence from a Meta-study across Six European Countries. British Journal of Political Science. doi:10.1017/Sooo7123416000521

Bhatti, Y., Dahlgaard, J. O., Hansen, J. H., \& Hansen, K. M. (2017). Moving the campaign from the front door to the front pocket: field experimental evidence on the effect of phrasing and timing of text messages on voter turnout. Journal of Elections, Public Opinion and Parties, 27(3), 291-310. doi:10.1080/17457289.2016.1270288

Bond, R.M., Fariss, C.J., Jones, J.J., Kramer, D.I., Marlow, C., Settle, J.E., \& Fowler, J.H. (2012). A 61-million-person experiment in social influence and political mobilization. Nature, 498, 295-298. doi:10.1038/nature11421

boyd, D. (2014). It's complicated: The social lives of networked teens. New Haven, CT: Yale University Press.

Common Sense Media. (2012). Social media, social life: How teens view their digital lives. Retrieved from https://www.commonsensemedia.org/research/social-media-social-life-howteens-view-their-digital-lives

Dale, A. \& Strauss, A. (2009). Don't forget to vote: Text message reminders as a mobilization tool. American Journal of Political Science, 53(4), 787-804. doi:10.1111/j.1540-

5907.2009.00401.x

Davenport, T. (2008). Unsubscribe: Comparing the effects of peer-to-peer and mass email messages on voter turnout. Poster presented at the Annual Meeting of the American Political Science Association, Boston, MA.

de Figueiredo, M.F.P., Hidalgo, F.D., \& Kasahara, Y. (2014). When do voters punish corrupt politicians? Experimental Evidence from Brazil. (Unpublished manuscript).

Fieldhouse, E., Cutts, D., Widdop, P., \& John, P. (2013). Do impersonal mobilization methods work? Evidence from a nationwide get-out-the-vote experiment in England. Electoral Studies, 32(1), 113-123. doi:10.1016/j.electstud.2012.09.003

Druckman, J.N., Green, D.P., Kuklinski, J.H., \& Lupia, A. (Eds.). (2011). Handbook of experimental political science. New York: Cambridge University Press.

Fujiwara, T. (2015). Voting technology, political responsiveness, and infant health: Evidence from Brazil. Econometrica, 83(2), 423-464. doi:10.3982/ECTA11520

García Bedolla, L. \& Michelson, M.R. (2012). Mobilizing inclusion: Transforming the electorate through get-out-the-vote campaigns. New Haven, CT: Yale University Press. 
Gerber, A.S. \& Green, D.P. (2000). The effects of canvassing, telephone calls, and direct mail on voter turnout: A field experiment. American Political Science Review, 94(3), 653-63.

doi:10.2307/2585837

Gerber, A.S., Green, D.P., \& Larimer, C.W. (2008). Social pressure and voter turnout: Evidence from a large-scale field experiment. American Political Science Review, 102, 33-48.

doi:10.1017/Sooo305540808009X

Gerber, A.S., Gimpel, J.G., Green, D.P., \& Shaw, D.R. (2011). How large and long-lasting are the persuasive effects of televised campaign ads? Results from a randomized field experiment. American Political Science Review, 105(1), 135-150. doi:10.1017/Sooo305541000047X

Glickhouse, R. (2015, January 15). How Brazil's cell phone boom is shaking up politics and journalism. Christian Science Monitor. Retrieved from

https://www.csmonitor.com/World/Americas/Latin-

America-Monitor/2015/o115/How-Brazil-s-cell-

phone-boom-is-shaking-up-politics-and-journalism

Green, D.P. \& Vavreck, L. (2006, April). Assessing the turnout effects of rock the vote's 2004 television commercials: a randomized field experiment. Paper presented at the Annual Meeting of the Midwest Political Science Association, Chicago, IL.

Green, D.P., \& Gerber, A.S. (2015). Get out the vote! How to increase voter turnout, 3rd ed. Washington, D.C.: Brookings Institution Press.

Haenschen, K. (2016). Social Pressure on Social Media: Using Facebook Status Updates to Increase Voter Turnout. Journal of Communication. 66(4), 542-563. doi:10.1111/jcom.12236

Idoeta, P.A. (2014, September 10). Candidatos jovens usam Facebook e WhatsApp em busca de eleitores. BBC Brasil. Retrieved from

http://www.bbc.com/portuguese/noticias/2014/o9/140904_eleicoes2014_jovenspoliticos_sal asocial_pai

Issenberg, S. (2012). The victory lab: The secret science of winning campaigns. New York, NY: Crown Publishers.

Liegéy, G., Muller, A., \& Pons, V. (2013). Porte à Porte: Reconquéir la Démocratie Sur le Terrain. Paris, France: Calmann-Lévy.

Malhotra, N., Michelson, M.R., Rogers, T., \& Valenzuela, A.A. (2011). Cold text messages as mobilization tools: Implications for theories of political participation. American Politics Research, 39(4), 664-681. doi:10.1177/1532673X11398438

Malhotra, N., Michelson, M.R., Rogers, T., \& Valenzuela, A.A. (2012). Research note: Emails from official sources can increase turnout. Quarterly Journal of Political Science, 7(3), 321-332. doi:10.1561/100.00011073

Mann, C.B. 2010. Is there backlash to social pressure? A large-scale field experiment on voter mobilization. Political Behavior, 32(3): 387-408. doi:10.1007/s11109-010-9124-y

Mann, C.B. \& Klofstad, C.A. (2015). The role of call quality in voter mobilization: Implications for electoral outcomes and experimental design. Political Behavior, 37(1), 135-154. 
doi:10.1007/s11109-013-9264-y

Matland, R.E. \& Murray, G.R. (2013). An experimental test for "backlash" against social pressure techniques used to mobilize voters. American Politics Research, 41(3), 359-386. doi:10.1177/1532673X12463423

Michelson, M.R., García Bedolla, L., \& McConnell, M.A. (2009). Heeding the call: The effect of targeted two-round phonebanks on voter turnout. Journal of Politics, 71(4), 1549-1563.

doi:10.1017/Soo22381609990119

Nickerson, D.W. (2006). Volunteer phone calls can increase turnout: Evidence from eight field experiments. American Politics Research, 34(3), 271-92. doi:10.1177/1532673X05275923

Nickerson, D.W. (2007a). Quality is job one: Professional and volunteer voter mobilization calls. American Journal of Political Science, 51(2), 269-282. doi:10.1111/j.1540-5907.2007.00250.x

Nickerson, D.W. (2007b). Does email boost turnout? Quarterly Journal of Political Science, 2(4), 369-79. doi:10.1561/100.00007032

Panagopoulos, C. (2010). Affect, social pressure and prosocial motivation: Field experimental evidence of the mobilizing effects of pride, shame and publicizing voting behavior. Political Behavior, 32(3), 369-386. doi:10.1007/s11109-010-9114-0

Panagopoulos, C. \& Green, D.P. (2011). Spanish-language radio advertisements and Latino voter turnout in the 2006 congressional elections: Field experimental evidence. Political Research Quarterly, 64(3), 588-599. doi:10.1177/1065912910367494

Peixoto, T., Sjoberg, F., \& Mellon, J. (2017). A Get Out The Vote (GOTV) Experiment on the World's Largest Participatory Budgeting Vote in Brazil. British Journal of Political Science. https://ora.ox.ac.uk/objects/uuid:d4doge70-35od-4140-9b95-487b3f5c6245

Putnam, R.D. (2000). Bowling alone: the collapse and revival of American community. New York: Simon \& Schuster.

Regan, J. (2013). The Effects of Direct Mail on Voter Turnout: A Randomized Field Experiment. Unpublished manuscript, University of Birmingham, Department of Economics.

Rogers, T., Green, D.P., Ternovski, J., \& Ferrerosa Young, C. (2017). Social pressure and voting: A field experiment conducted in a high-salience election. Electoral Studies, 46: 87-10o.

Rosenstone, S.J. \& Hansen, J.M. (1993). Mobilization, participation, and democracy in America. New York: Macmillan.

Statista. (2017a). Most popular mobile messaging apps worldwide as of January 2017, based on number of monthly active users (in millions). Retrieved from https://www.statista.com/statistics/258749/most-popular-global-mobile-messenger-apps/

Statista. (2017b). Most popular mobile messaging apps amongst Android users in the United States as of 1st quarter 2016, by daily usage (in minutes.seconds). Retrieved from https://www.statista.com/statistics/258681/mobile-messenger-app-usage-ofusers-in-the-united-states/

Stollwerk, A. (2015). Does partisan e-mail affect voter turnout? An examination of two field 
experiments in New York City. Unpublished manuscript, Columbia University, Department of Political Science.

Teresi, H. \& Michelson, M.R. (2014). Wired to mobilize: The effect of social networking messages on voter turnout. Social Science Journal, 52(2): 195-204. doi: 10.1016/j.soscij.2014.09.004.

Teixeira, M. (2014, November 28). 5 Ways that WhatsApp is used by businesses in Brazil. TechinBrazil. Retrieved from https://techinbrazil.com/5-ways-that-whatsapp-is-used-bybusinesses-in-brazil

Thompson, D. (2014, June 19). The most popular social network for young people? Texting. The Atlantic. Retrieved from https://www.theatlantic.com/technology/archive/2014/o6/facebooktexting-teens-instagram-snapchat-most-popular-social-network/373043/

\section{APPENDIX: RANDOMISATION CHECKS (T-TESTS)}

$\begin{array}{lllllll}\text { WhatsApp } & \begin{array}{l}\text { Door-to- } \\ \text { door }\end{array} & \text { Email } & \text { Robocall Control } \mathrm{H}_{\mathrm{o}}: & \mathrm{H}_{\mathrm{o}}: & \mathrm{H}_{\mathrm{o}}: & \mathrm{H}_{\mathrm{o}} \text { : } \\ \text { treatment } & \text { treatment treatment group } & \mathrm{W}=\mathrm{C} & \mathrm{D}=\mathrm{C} & \mathrm{E}=\mathrm{C} & \mathrm{R}=\mathrm{C} \\ \text { group (W) } & \begin{array}{l}\text { treatment } \\ \text { group (D) }\end{array} & \text { group (E) group (R) (C) } & \text { p-value } & \text { p-value } & \text { p-value } & \text { p-value }\end{array}$

Amazonas $<18$

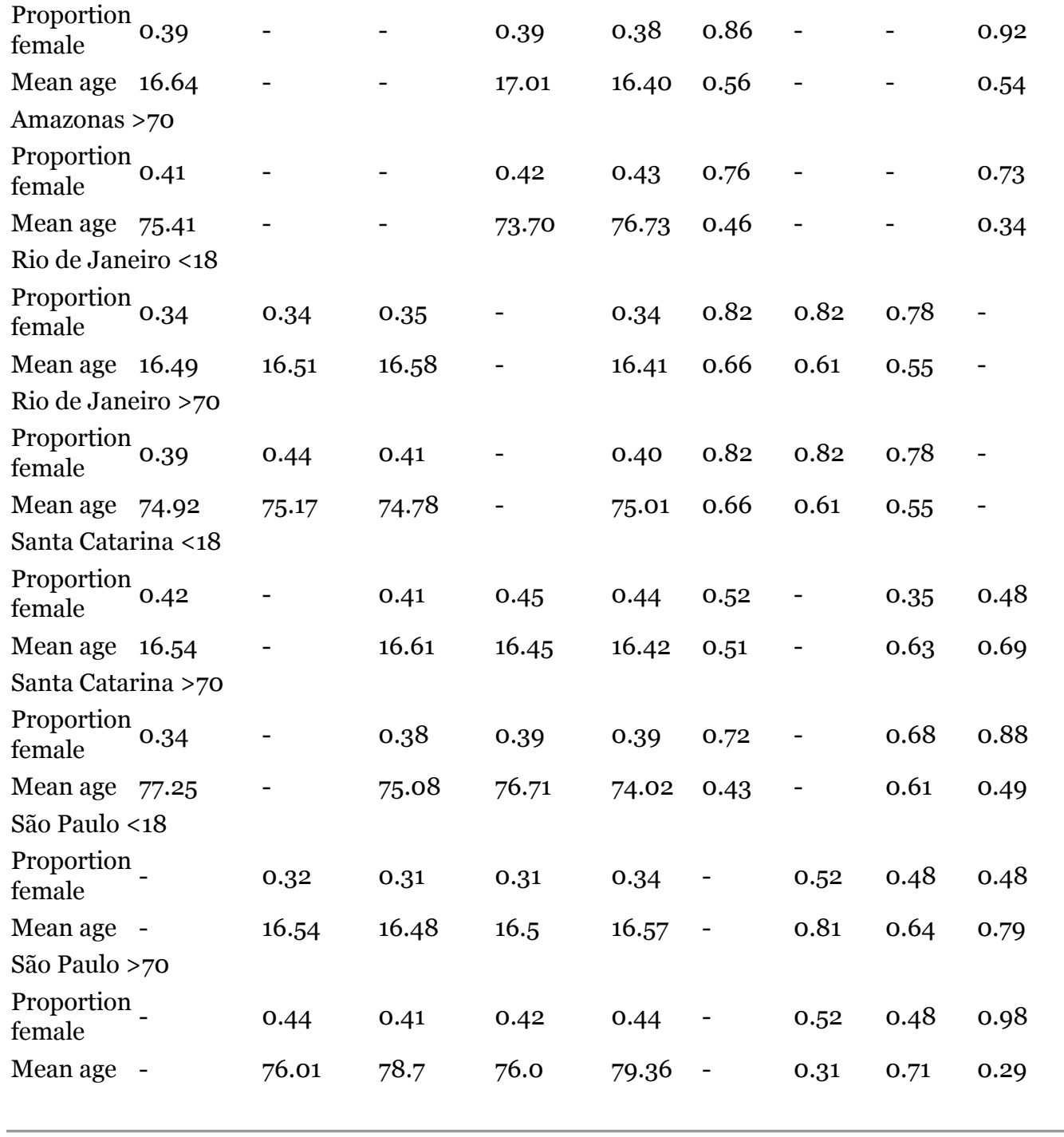




\section{FOOTNOTES}

1. WhatsApp's Terms of Service (www.whatsapp.com/legal/) prohibits sending advertisements or messages using an automated system "that accesses the Service in a manner that sends more request messages to the WhatsApp servers in a given period of time than a human can reasonably produce in the same period by using a WhatsApp application". In the field, candidates often found their WhatsApp channels shut down (e.g., after sending 50,000 messages) and had to rejoin the service with a new account.

2. http://www.idea.int/americas/the-elections-in-brazil.cfm 